\title{
SOUTHERN JUDICIAL DISTRICT OF IOWA
}

\section{By NICHOLAS F. REED ${ }^{1}$}

Iowa was organized as a territory in 1838 with Burlington as the territorial capital. Upon the reorganization of the territory Pesident Van Buren appointed as the judges of the territorial court, Charles Mason, Joseph Williams and Thomas S. Wilson, Mr. Mason being named as the chief justice. The first court was held by Judge Williams at Fort Des Moines. All three of these judges were reappointed to office in 1842 by President Tyler and again in 1846 by President Polk.

The clerks of the Federal court who held office during this territorial period were Thornton Bayless from 1838 to 1840 and George S. Hampton from 1840 to 1846 ; the United States district attorneys were Isaac Van Allen, who held office from 1838 to 1840 , Charles Weston 1840 to 1843 , John G. Deshler from 1843 to 1845, and Edward Johnston in 1845 and 1846; and the United States marshals for the same period were Francis Gehon from 1838 to 1840 , Thomas B. Johnston during the years 1841 and 1842, Isaac Leffler from 1842 to 1845 and Gideon S. Bailey in 1845 and 1846.

Congress established the United States district court of Iowa by an act which was approved March 3, 1845 . The state was then one district called the District of Iowa, and one judge was appointed for the district, John J. Dyer of Dubuque, a native of Virginia, whose appointment was made in 1846. The first session of this court was held in Burlington on October 15, 1849, with Judge Dyer presiding. He passed away in 1856 and was succeeded in office by James M. Love.

James M. Love was born in Fairfax, Virginia, in 1820, and located at Keokuk, Iowa, in 1850. His commission as United States district judge for Iowa was granted by President Pierce under date of February 21, 1856, and he

${ }^{1}$ Clerk of U. S. district court, Southern district of Iowa, Des Moines. 
served in that capacity for 35 years until his death in 1891 at Keokuk.

For the first two years of Judge Love's incumbency little business occupied the district court, but it increased rapidly in the succeeding years with multiplied subjects of litigation.

As an associate judge of the circuit court, Judge Love took an active part in its business, sharing the labors of the circuit judge, and was often called to continue the trial of causes after the presiding judge was compelled to leave to open the session of his court in some other district of his widély extended circuit. But not alone to judicial matters in open court was the time of Judge Love devoted. In the transaction of business in chambers, his continued presence in the district afforded facilities to parties to apply to him for relief on preliminary and summary motions, and matters of great weight were then often argued and decided.

\section{DIVISION OF DISTRICT}

Of interest here is the division of our local United States district court from 1845 to 1911 into a circuit court and a district court, both courts being served by the local federal judge. For instance, when Judge Dyer was holding circuit court he was judge of the United States circuit court for the District of Iowa, and when he was holding the district court he was judge of the United States district court for the District of Iowa. These were separate courts with distinct jurisdictions.

At the very beginning of our government, by the first judiciary act of 1789, congress created the inferior courts below the United States supreme court as the district and circuit courts of the United States. The country was then divided up into thirteen districts wherein both district and circuit courts were set up, but only district judges were appointed. The business of the district courts 
was handled singly by the local distict judge, but congress provided that the business of the circuit courts should be handled by an associate justice of the supreme court sitting with the local district judge. This system continued until 1869 when congress created the new judgeship of United States circuit judges. Thereafter the supreme court justices stayed at Washington for the most part and the work of the circuit courts was presided over by the new circuit judges until 1892 when the circuit court of Appeals was organized. The work of the circuit at courts continued to increase so much also that it was provided at an early date that the circuit court could be held singly by the local district judge, and our records show that most of the business in Iowa was handled by the district judge.

Briefly the jurisdiction of the circuit courts included all civil business, both law and equity, and the district courts included all the criminal business. However, the jurisdiction of both courts in many criminal matters was concurrent, but we find most of the civil business being handled by the local circuit judges.

\section{LiNCOLN Elevated Iowa MAN}

Samuel Freeman Miller was the first United States supreme court judge to be appointed from Iowa. He was born in Richmond, Kentucky, on April 5, 1816, and settled in Keokuk, Iowa, in 1850. His first preparation was to be a doctor of medicine but after completing that study he turned to law, in which field he became one of the really great jurists of the United States. His appointment to the supreme court was made by President Lincoln in 1862 and he was assigned to the Eighth circuit, and in that capacity he presided over the local circuit courts. The reports carry many cases in which Judge Miller sat as the trial judge in the circuit courts of Iowa and the sursounding states of the Eighth circuit from 1862 to 1890.

The first new United States circuit judge under the Act of 1869 for the Eighth circuit was an Iowa lawyer, 
John Forrest Dillon. Judge Dillon, eminent jurist and legal author, was born in Northampton, New York, on December 25, 1831. In 1838 his parents moved to Davenport, Iowa, where he lived for 41 years or until his removal to New York City in 1879. John F. Dillon was graduated as a physician from the College of Physicians and Surgeons at Davenport, Iowa, in 1850 at the age of 19 , but turned to the study of law within a very short time. He was elected a Judge of the Seventh judicial district of Iowa in 1858, and also elected to the supreme court of Iowa where he served for a term of six years from 1863 . He was re-elected in 1869 and was chief justice of that body, but before he qualified for his second term he was appointed by President Grant as United States circuit judge of the Eighth judicial circuit embracing Iowa and other nearby states, in which capacity he served for ten years. Following Judge Dillon's appointment most of the work of the circuit court in Iowa was held with him presiding, although Justice Miller continued to come to Iowa until the time of his death. It has been said that no son of Iowa has conferred a more substantial and enduring honor upon her name than John F. Dillon.

\section{Three Court Divisions Created}

The United States district court for Iowa was separated into three divisions by an act of congress dated February 26, 1853, thereby creating the Northern, Central and Southern divisions of the district and providing that court be held at Dubuque, Iowa City and Burlington. On March 3, 1859, congress approved an act which provided that the district again be divided into three divisions, this time the Northern, Southern and Western divisions, with court designated to be held at Dubuque, Keokuk and Des Moines.

George W. McCrary, who succeeded Judge John F. Dillon as a United States circuit judge, was born in Evansville, Indiana, on August 29, 1835, and died in St. Joseph, Missouri, on June 23, 1890, at the age of 55. In 1837 he 
moved to Van Buren county, Iowa, where he was admitted to the bar in 1856 and practiced law in Keokuk for a number of years. He was appointed secretary of war in 1877 , and in 1879 he resigned the cabinet position to accept the appointment of United States circuit judge for the Eighth circuit and assumed his judicial duties in January 1880. Judge McCrary resigned the judgeship to become general counsel for the Atchison, Topeka and Santa Fe railroad company, and was succeeded in office by David J. Brewer of Leavenworth, Kansas, who was commissioned a United States circuit judge on March 31, 1884.

Upon Judge Brewer's appointment as an associate justice of the United States supreme court by President Harrison in 1890, Henry C. Caldwell, who was a United States district judge for the District of Arkansas, was appointed as United States circuit judge for this circuit. He retired from the federal bench in 1903 after continuous service of forty years, both as a United States district judge residing in Arkansas and as a circuit judge of this circuit from 1890.

Upon the creation of the United States circuit court of appeals in 1892, President Harrison appointed Walter $\mathbf{H}$. Sanborn of St. Paul and Amos M. Thayer of St. Louis as the new United States circuit judges. The court of appeals for the Eighth circuit was therefore composed of Judges Caldwell, Sanborn and Thayer in rank of seniority.

The circuit courts were abolished or rather merged with the district courts by the act of 1911, and all jurisdiction was vested in the district courts.

Another United States circuit judge from Iowa was Walter I. Smith, who was born at Council Bluffs, Iowa, on July 10, 1862, and was appointed a judge of the United States circuit court of appeals on January 31, 1911. Other Iowans serving upon the circuit court of appeals for this circuit were William S. Kenyon and Seth Thomas of Fort 
Dodge, Iowa. Judge Archibald K. Gardner, another member of the court of appeals for this circuit was born and raised in Jasper county, Iowa, but was appointed from South Dakota.

\section{Iowa Divided InTo Two Districts}

On July 20, 1882, the United States district court in Iowa was divided into the Northern and Southern districts with three divisions in each. In the Southern district of Iowa court was held at Council Bluffs, Des Moines and Keokuk. Three additional divisions were later created, namely, the Southern division on June 1, 1900, with court to be held at Creston; the Davenport division on April 28, 1904, with Davenport designated as the place for holding court; and the Ottumwa division on February 20, 1907, with court to be held at Ottumwa.

John S. Woolson was born in Eric County, New York, in 1840 and moved with his parents to Henry county, Iowa, in 1856. In 1891 he was appointed by President Harrison as judge of the United States district court for the Southern district of Iowa, which position he held at the time of his death only eight years after his appointment.

Smith McPherson of Red Oak, Iowa, was appointed as judge of the district court of the United States for the Southern district of Iowa by President McKinley in 1899, and filled the position until his death fifteen years later.

Martin J. Wade of Iowa City was born in Burlington, Vermont, on October 21, 1861, becoming a resident of Iowa when his parents moved to the state while he was quite young, and he made his home at Iowa City for many years. On March 3, 1915, he was appointed by President Wilson as judge of the United States district court for the Southern district of Iowa to succeed Smith McPherson, and held that position until his death on April 16, 1931.

Charles A. Dewey of Washington, Iowa, was appointed judge of the United States district court for the Southern 
district of Iowa by President Calvin Coolidge on January 31,1928 , and continues in that office at the present time..

\section{CLERKS OF COURT}

Considering the length of time that has elapsed since the formation of federal courts in Iowa, the number of clerks both of the United States district court and the circuit court has been few.

T. S. Parvin was born in Cedarville, New Jersey, on January 15, 1817, and died at Cedar Rapids, Iowa, on June 28, 1901. He was clerk of the United States District Court in Iowa from 1847 to 1857. J. C. Burns was the second clerk of the United States district court in this state and served for a number of years following his appointment in 1858.

William G. Woodward was born in Hanover, New Hampshire in 1808 and came to Muscatinè, then known as Bloomington, Iowa, from Boston in 1839, only five years after the territory was opened for white settlement. He was appointed one of the three commissioners who framed the first code for the new state of Iowa, which was known as the "Code of 1851". He was appointed clerk of the circuit court of the United States in 1863 and died on February 24, 1871.

George B. Corkhill was born in Harrison county, Ohio, in 1838, and when nine years of age removed to Mount Pleasant, Iowa, with his family. Later in life he was clerk of the United States district court in Iowa, and he, with Ed R. Mason and William C. McArthur, were the clerks of the circuit court of the United States in this state. Upon the resignation of William G. Woodward as clerk of the United States circuit court, Mr. Corkhill was appointed clerk of that court on December 10, 1868.

Henry K. Love was appointed clerk of the United States district court in Iowa in April 1868 and served in that capacity for a number of years. 
Ed R. Mason of Des Moines, Iowa, served as clerk of the United States district court and as clerk of the circuit court also, having received his commission on December $13,1875$.

John J. Steadman of Council Bluffs, Iowa, was commissioned clerk of the United States district court in Iowa on January 15, 1892, and was succeeded in that office by William C. McArthur of Des Moines.

William C. McArthur was born in Burlington, Iowa, on July 22, 1860, and now resides in Des Moines. He began the practice of law in Burlington in July 1882 and continued his practice until appointed clerk of the United States district court for the Southern district of Iowa on January 1, 1901. On April 1, 1910, Mr. McArthur was also appointed clerk of the circuit court, and was our last circuit court clerk.

Nicholas F. Reed of Ottumwa, Iowa, now a resident of Des Moines, succeeded Mr. McArthur as clerk of the United States district court, to which office he was appointed on April 1, 1922, and continues as clerk at the present time.

\section{U. S. DistriCT ATtORNEYS}

We will sketch briefly the district attorneys and marshals who have served the United States district court for Iowa and particularly for the Southern district of Iowa. Isaac M. Preston of Marion, Iowa, a native of Vermont, was appointed United States district attorney for Iowa in 1847, and our second United States district attorney was Stephen .Whicher of Muscatine, who vas appointed to that post by President Fillmore in 1850.

Joseph C. Knapp settled in Keosauqua, Iowa, in 1843, and in 1852 was appointed by President Pierce as United States district attorney for Iowa. He was reappointed to the same office by President Buchanan and held it for eight years. W. H. F. Gurley served as United States 
district attorney in the early 1860's or between the terms of Joseph C. Knapp and Robert H. Gilmore.

Robert H. Gilmore was born in Newark, Ohio, in 1822 , and came to Keokuk, Iowa, in 1857. He was given the appointment of United States district attorney by President Lincoln and served as such from 1863 to 1865.

Caleb Baldwin was born in Pennsylvania in 1824 and came to Fairfield, Iowa, in 1842. In 1865 he was appointed by President Lincoln to the office of United States district attorney for Iowa, but served only a short time. He died at his home in Council Bluffs in December 1876 at the age of 52 .

Milton D. Browning came to Burlington, Iowa, from Kentucky in 1837. In 1867 he was appointed by President Johnson as United States district attorney in Iowa and served until the close of the Johnson administration. He died in 1881.

William Fletcher Sapp of Council Bluffs, Iowa, was born at Danville, Ohio, on November 20, 1824. He was appointed United States district attorney for the state of Iowa by President Grant in 1869, filling the office for four years with honor and credit. During the time he was a representative from the Eighth congressional district he introduced and secured the passage of a bill providing for holding the United States circuit courts at the times and places where the United States district courts were then held, namely at Dubuque, Des Moines, Keokuk and Council Bluffs.

James T. Lane, a native of Freeport, Pennsylvania, where he was born in 1830 , settled in Davenport, Iowa, in 1854. In 1873 he was appointed by President Grant as United States district attorney for Iowa, and served in that position for nine years.

John S. Runnells was born in New Hampshire in 1844 and came to McGregor, Iowa, in 1867. He was appointed to the position of United States district attorney in 1882, 
and was followed in office by Daniel O. Finch who came to Iowa from Monroe, Wisconsin, and settled at Cedar Rapids. From there he moved to Des Moines and in $\mathbf{1 8 8 5}$ was appointed by President Garfield to the position of United States district attorney for the Southern district of' Iowa.

Lewis Miles served as United States district attorney for a short period following his appointment on March 18,1890 , and was followed in office by Charles D. Fullen of Fairfield, Iowa, who was commissioned to the office on December 19, 1893.

Marcellus L. Temple of Osceola, Iowa, was born in Madestown, West Virginia, on September 16, 1848, his family having originiated in Leicestershire, England, as early as 1070. He was commissioned United States district attorney for the Southern district of Iowa in 1907.

Claude R. Porter of Centerville, Iowa, was appointed United States district attorney on February 25, 1914, and following his resignation Edwin G. Moon of Ottumwa was appointed to the office. Ralph Pringle of Red Oak followed Mr. Moon's first term as United States district attorney when he was appointed to the office on April 11, 1922. When a vacancy was created in the position caused by the death of Mr. Pringle, Judge Martin J. Wade appointed Mr. Moon to again become district attorney from the date of April 8, 1924.

On May 17, 1924, Ross R. Mowry of Newton, Iowa, was appointed by President Warren G. Harding as United States district attorney for the Southern district of Iowa, and on May 26, 1932, Robert W. Colflesh of Des Moines took the oath of office following his appointment to that office.

Edwin G. Moon of Ottumwa, Iowa, was appointed to the position of United States district attorney in this district for a third time and took the oath of office on June 30, 1934, and upon his death Judge Chas. A. Dewey appointed Cloid I. Level to the position on Jauuary 23, 1939. 
On May 26, 1939, John K. Valentine of Centerville, Iowa, took the oath of office as United States attorney following his appointment to the position by President Franklin D. Roosevelt, and upon his resignation the court appointed Hugh Ben McCoy of Oskaloosa to act as United States attorney on April 19, 1940. The next United States attorney for the Southern district of Iowa, Maurice F. Donegan of Davenport, Iowa, was appointed on June 26, 1940, and took the oath of office on July 1, 1940. His term expired in March, 1949, and President Truman appointed as successor, William R. Hart, of Iowa City, the present United States attorney for the Southern district of Iowa.

\section{United States MarshaLs}

The office of United States marshal has been filled successively from the erly days of the court in the state of Iowa to the present time by the following men: Stephen Shelledy served from 1849 to 1853 ; Laurel Summers from October 17, 1853; H. M. Hoxie from the early 1860 's until the appointment of Gen. George N. Clark by President Grant in 1868.

Peter Melendy of Cedar Falls, Iowa, was appointed United States marshal in Iowa on March 10, 1874, and John W. Chapman of Council Bluffs, Iowa, followed him with an appointment on March 11, 1875. Richard Root of Keokuk, Iowa, served as marshal for a shorter term than Mr. Chapman after his appointment on February 28, 1883, until Edward Campbell, Jr., of Fairfield was appointed on January 27, 1886 . He was followed in office by Frank P. Bradley of Council Bluffs, who was appointed on February 28, 1894, and George M. Christian of Des Moines served as marshal from the date of his appointment on February 28, 1898. He was followed in office by Frank B. Clark of Ottumwa, Iowa, who was appointed on December 10, 1907, and Bernhardt J. Ness of Des Moines filled the office after his appointment by the court on November 26, 1913. 
Nicholas F. Reed of Ottumwa followed the short term of Mr. Ness as United States marshal and held the office for eight years from the date on which he took the oath of office, March 17, 1914. Mr. Reed was followed as marshal by Guy S. Brewer of Des Moines, who was appointed on March 21, 1922, and the following men have held the office of United States marshal from the dates of their respective appointments: I. H. Hammond of Des Moines, Iowa, appointed August 27, 1923; Roy B. Gault of Creston, appointed January 14, 1924; Fred S. Hird of Des Moines on February 4, 1928; George E. Miller of Harlan on March 6, 1936; and James J. Gillespie of Des Moines, the present marshal for the Southern district of Iowa, who was appointed to office on May 17, 1941.

This short sketch seeks to give a comprehensive outline of the formation of the court and brief authentic data concerning the judges and other officials connected therewith.

\section{"WHO SAVES HIS COUNTRY"}

In the monumental and stately capitol building at Atlanta, Georgia, stands the life-sized marble figure of Benjamin Harvey Hill, which once stood at a prominent street junction in the city. A former American ambassador to Great Britain, John W. Davis, recently requested a copy of the inscription, Mr. Hill's own words, and said it was one of the most outstanding utterances of any American statesman. It reads :

"Who saves his country, saves himself, saves all things, and all things saved do bless him. Who lets his country die lets all things die, dies himself ignobly, and all things dying curse him." 
Copyright of Annals of Iowa is the property of State of Iowa, by \& through the State Historical Society of Iowa and its content may not be copied or emailed to multiple sites or posted to a listserv without the copyright holder's express written permission. However, users may print, download, or email articles for individual use. 